\title{
Retraction
}

\section{Retracted: Rhinosporidiosis of the Parotid Duct}

\author{
Case Reports in Dentistry \\ Received 18 August 2014; Accepted 18 August 2014; Published 25 August 2014 \\ Copyright (C) 2014 Case Reports in Dentistry. This is an open access article distributed under the Creative Commons Attribution \\ License, which permits unrestricted use, distribution, and reproduction in any medium, provided the original work is properly \\ cited.
}

The paper entitled "Rhinosporidiosis of the Parotid Duct" [1], published in Case Reports in Dentistry, has been retracted as it was submitted without the knowledge or consent of Dr. Premalatha Shetty who was responsible for the patient whose case was presented in the manuscript. Also, the manuscript includes false data, as the presented case was originally reported and treated in a hospital at Mangalore, India, in 2009 and not in Nepal.

\section{References}

[1] S. K. Yadav and S. Shrestha, "Rhinosporidiosis of the parotid duct," Case Reports in Dentistry, vol. 2014, Article ID 131794, 5 pages, 2014. 